\title{
PROTECTING MINORS FROM THEMSELVES: EXPANDING ReVENGe PORN LAWS TO PROTECT THE MOST VULNERABLE
}

\author{
Mitchell OSTERDAY*
}

\section{INTRODUCTION}

In late 2013, a Facebook page featuring nude pictures of several female students from Durfee High School shocked families, friends, and classmates in the small community of Fall River, Massachusetts. ${ }^{1}$ By the time the students depicted in the photographs began to realize their exposed bodies were now in cyberspace for everyone to view, the damage had already been done. ${ }^{2}$ An investigation by local police revealed that some of the victims of these nonconsensual posts were as young as sixteen-years-old. ${ }^{3}$ When asked her opinion of the pictures that were posted on the website, one student remarked, "It definitely affects people but I mean they got there for a reason. They were probably sent to someone in a relation [sic] and got out onto the Internet." ${ }^{4}$ Another student echoed this sentiment, simply stating, "It is just so irresponsible."

Although it may be unsurprising to most observers that a seventeen-year-old boy was responsible for creating this Facebook page and posting the pictures, it is startling to learn that local prosecutors charged him with "dissemination of obscene material harmful to minors, and possessing child pornography." If convicted on these charges, this teenager would be labeled a sex offender and would receive a minimum ten-year prison sentence. ${ }^{7}$ Given these circumstances, a conviction of possession and dissemination of child pornography would be unconscionable. Laws must change to give prosecutors better tools that provide more appropriate punishments for this activity. Laws must also adapt to teenagers' expanding access to new technologies by allowing greater flexibility in the terminology used in the statute.

* J.D. Candidate, 2017, Indiana University Robert H. McKinney School of Law; B.A., Social Studies Education (2012), Purdue University. Thank you to Professor Yvonne Dutton for all of your guidance and encouragement. Special thank you to my friends and family for their extreme patience, unending support, and thoughtful prayers.

1. Melissa Randall, Teen Arrested for Naked Picture Postings on Facebook, ABC6 WLNETV (Feb. 13, 2014, 7:56 PM), www.abc6.com/story/24591196/graphic-images-of-fall-river-teensshow-up-on-facebook [perma.cc/6492-XHVQ].

2. Id.

3. $I d$.

4. $I d$.

5. Id.

6. Samuel Goldberg, Fall River High School Student Is Arrested for the Dissemination of Child Pornography, Bos. CRIM. LAw. BlOG (Feb. 3, 2014), www.bostoncriminallawyerblog. com/2014/02/fall_river_high_school_student_1.html [perma.cc/G6T6-GJYN].

7. $I d$. 
The Facebook page created in Fall River was likely made possible because today's teenagers live in a connected world with instant access to pictures, videos, and updates from an ever-expanding list of websites, social networking sites, and third-party smartphone applications. A recent Pew Research study revealed 78\% of children ages twelve to seventeen own a cell phone and almost half of those $78 \%$ own a smartphone. ${ }^{8}$ Additionally, data shows that as hardware costs decline, more teenagers are gaining access to devices with the ability to access the Internet. ${ }^{9}$ The same Pew Research study found that $93 \%$ of teenagers have access to either a computer or a tablet ${ }^{10}$ and $25 \%$ of teenagers identify their cell phone as the primary tool by which they access the Internet. ${ }^{11}$

Teenagers have found new methods of self-expression through expanded access to smartphones and the Internet. ${ }^{12}$ In some instances, this self-expression comes in the form of a phenomenon known as "sexting."13 Sexting is "the practice of sending or posting sexually suggestive text messages and images, including nude or semi-nude photographs, via cellular telephones or over the Internet. ${ }^{14}$ In a recent Drexel University study, $54 \%$ of college students admitted to having sent graphic or explicit texts before the age of eighteen. ${ }^{15}$

The frequency at which teenagers send nude material is alarming, especially considering the potential danger of those images being leaked onto the Internet without the permission of the sender. ${ }^{16}$ Teenagers who release explicit images of others without the consent of the party depicted in the picture damage the integrity and privacy of the individuals in the photos. ${ }^{17}$ There is often little consequence to an anonymous perpetrator's actions and there is next to nothing the victim may do to stop the post from spreading after it is on the Internet. ${ }^{18}$

The most accurate descriptor for this abuse of technology is "nonconsensual pornography," but the phenomenon has more recently come to be known as

8. Mary Madden et AL., Teens And Technology 20132 (Mar. 13, 2013), available at www.pewinternet.org/files/old-media//Files/Reports/2013/PIP_TeensandTechnology2013.pdf [perma.cc/ZL5Y-J6RQ].

9. See id. at 5 .

10. Id.

11. Id. at 7 .

12. Id.

13. A. Pawlowski, Seventh-graders Sexting? It Might Be More Common Than You Think, TODAY PARENTS (Jan. 6, 2014, 12:01 AM), www.today.com/parents/seventh-graders-sexting-itmight-be-more-common-you-think-2D11850722 [perma.cc/BF2J-CH2A].

14. Miller v. Mitchell, 598 F.3d 139, 144 (3d Cir. 2010).

15. Randye Hoder, Study Finds Most Teens Sext Before They're 18, Time (July 3, 2014), time.com/2948467/chances-are-your-teen-is-sexting/ [perma.cc/T4QZ-6PCW].

16. $I d$.

17. See Sameer Hinduja, Revenge Porn and the Purge Trend on Instagram and Twitter, Cyberbullying ReS. CTR. (July 25, 2014), cyberbullying.us/revenge-porn-purge-trend-instagramtwitter/ [perma.cc/FZ36-UPHC] (explaining how teenagers and adults took to Instagram and Twitter to post a high volume of explicit pictures of former boyfriends or girlfriends).

18. See id. 
"revenge porn." ${ }^{19}$ Revenge porn is defined in various ways, ${ }^{20}$ but is most often characterized as "the distribution of sexually graphic images of individuals without their consent." ${ }^{\text {21 }}$ The discussion on the dangers and attributes of revenge porn has gained traction in several states and, as of July 2015, twenty-six state legislatures have been compelled to enact some form of a revenge porn law. ${ }^{22}$ For those found guilty under these types of statutes, the law generally imposes criminal sanctions in the form of jail time, a monetary fine, or both. ${ }^{23}$

When looking at revenge porn statutes as they are currently written, there are several potential scenarios that could play out in the real world. First, in situations where the distributor of a graphic image and the victim of that non-consensual distribution are both adults, it would seem that revenge porn statutes would apply as they were intended. A second scenario could happen when an adult distributes graphic pictures of a minor. This scenario produces a simple outcome: the adult could be charged for dissemination or possession of child pornography. An interesting dilemma is presented in a third scenario where a minor transmits an explicit picture of another minor without their consent. How should the law treat teenagers who arguably may not know that their actions are inherently criminal and could even be considered distribution of child pornography much like the case in Fall River, Massachusetts? ${ }^{24}$ This Note proposes that existing and future state revenge porn statutes should be expanded to target minors who engage in this activity so prosecutors may more accurately charge the correct and appropriate offense. Additionally, this Note suggests that these statutes should include punishments tailored to the severity of the situation to deter the activity among repeat and future offenders.

This Note does not discredit other proposed remedies to the issue. Rather, this Note asserts that the serious nature of revenge porn among minors warrants particular scrutiny due to the nature of the issue and the age of the parties involved. Part I gives a brief history of revenge porn statutes and distinguishes them from similar statutes that already exist. Part II explores existing interpretations of revenge porn statutes and examines how narrow and broad statutes produce differing outcomes in specific cases. Part III discusses alternative remedies to criminalizing revenge porn. Finally, Part IV offers proposed language for fixing current law and offers a guidepost for future revenge porn legislation.

19. Frequently Asked Questions, END REVEnge PoRn, www.endrevengeporn.org/faqs/ [perma.cc/N9VH-2R6H] (last visited Oct. 6, 2015).

20. Compare CAL. Pen. COdE $\S 647(j)(4)(A)$ (2015) (requiring the person distributing the image know or should know that distributing will cause serious emotional harm by the nonconsensual release of a consensual photograph), with N.J. STAT. ANN. § 2C:14-9 (2004) (requiring only that the person who releases an intimate photograph of another not be licensed to do so).

21. Frequently Asked Questions, supra note 19.

22. Sameer Hinduja \& Justin W. Patchin, State Sexting Laws, Cyberbullying, www.cyberbullying.us/state-sexting-laws.pdf [http://perma.cc/V8RV-RAMN] (last updated July, 2015).

23. Id.

24. See Goldberg, supra note 6 . 


\section{Summary And Definition of ReVenge Porn}

Because the phenomenon of revenge porn is still a relatively new development in the law, the definition of what constitutes revenge porn varies between jurisdictions. ${ }^{25}$ Therefore, it is important to understand the evolution and rationale behind this kind of legislation before offering a proposal to target the conduct among teenagers.

\section{A. Definition of Revenge Porn}

Generally, revenge porn is "the posting of nude or sexually explicit photographs or videos of people online without their consent, even if the photograph itself was taken with consent. ${ }^{, 26}$ The distinguishing characteristic between regular pornography and revenge pornography is that scorned ex-lovers create revenge pornography by releasing nude images of their former partner. ${ }^{27}$ Though hard copies or digital photographs transmitted via text message or in person would likely fall under a revenge porn statute's purview, the explicit images addressed in this Note are frequently transmitted via the Internet. ${ }^{28}$

Before social media became a vehicle by which revenge porn could travel, there were, and continue to be, websites hosting revenge porn postings. ${ }^{29}$ These sites usually provide detailed information about the person depicted in the photograph, including the subject's full name, address, and links to his or her social media profiles. ${ }^{30}$ Perhaps the most famous example of a revenge porn website is the much maligned site Is Anyone Up $?^{31}$ The site's operator, Hunter Moore, became known as the "most hated man on the Internet" when he kept escaping liability for posting pictures of naked women, including their name,

25. Compare CAL. PEN. CODE. $\S 647(j)(4)(A)$ (requiring the person distributing the image know or should know that distributing will cause serious emotional harm by the non-consensual release of a consensual photograph), with N.J. STAT. ANN. § 2C:14-9 (requiring only that the person who releases an intimate photograph of another not be licensed to do so).

26. State 'Revenge Porn' Legislation, NAT'L Conf. St. Legis. (Oct. 9, 2014), www.ncsl.org/research/telecommunications-and-information-technology/state-revenge-pornlegislation.aspx [perma.cc/JAH8-FQBX] (information also on file with author).

27. See Frequently Asked Questions, supra note 19.

28. Zak Franklin, Justice for Revenge Porn Victims: Legal Theories to Overcome Claims of Civil Immunity by Operators of Revenge Porn Websites, 102 CAL. L. REV. 1303, 1306 (2014).

29. Jessica Roy, Revenge-Porn King Hunter Moore Indicted on Federal Charges, Time (Jan. 23, 2014), time.com/1703/revenge-porn-king-hunter-moore-indicted-by-fbi/ [perma.cc/RT6QWMX4].

30. Travis Crabtree, Regulating Revenge Porn and Explicit Online Communications with Children-Easier Said Than Done, EMedia L. Insider (Oct. 31, 2013), www.emedialaw.com/ regulating-revenge-porn-and-explicit-online-communications-with-children-easier-said-than-done/ [perma.cc/PJJ8-5K9B].

31. Roy, supra note 29. 
address, and social media contact information, without their consent. ${ }^{32}$ The site was eventually shut down in $2012,{ }^{33}$ though its effects are still being felt today through copycat sites. ${ }^{34}$

Even with state revenge porn statutes as they exist today, Internet companies that host sites of this nature are shielded from direct liability through protections under Section 230 of the Communications Decency Act, ${ }^{35}$ which provides immunity to Internet hosts for the content that their operators post. ${ }^{36}$ This type of immunity was invoked in a recent case from Texas where GoDaddy, an interactive Internet service provider, hosted the explicit content of a third-party revenge porn site. ${ }^{37}$ In GoDaddy.com, LLC v. Hollie Toups, the plaintiff alleged that GoDaddy was liable for the graphic material on the site that was hosted on GoDaddy's servers. ${ }^{38}$ The plaintiff further noted that some of the images constituted child pornography because they depicted images of minors and that GoDaddy either knew or should have known that the content was illegal or of an explicit nature. ${ }^{39}$ The court rejected this claim, finding that Section 230 provides immunity for Internet service providers like GoDaddy even in instances of hosting child pornography. ${ }^{40}$

The main reason this topic is so important is that there are very real harms experienced by victims that may have a lasting impact on how they interact with society. ${ }^{41}$ Revenge porn is harmful because it can lead to stalking, harassment, decreased job prospects, and even suicide. ${ }^{42}$ Victims of revenge porn have reported feeling humiliation, concern for personal safety, a need for hypervigilance when exploring self-expression, and body shame. ${ }^{43}$ One victim reported

32. Id.

33. Id.

34. See, e.g., Eric Larson, It's Still Easy to Get Away With Revenge Porn, Mashable (Oct. 21, 2013), http://mashable.com/2013/10/21/revenge-porn/ [http://perma.cc/X3DE-CDMS] (explaining that one victim of revenge porn claims she still receives threatening phone calls and private messages on social media sites after her nude photos were released on a copycat site called "Texxxan").

35. 47 U.S.C. $§ 230(f)(3)(1998)$.

36. See generally Casey Martinez, An Argument for States to Outlaw 'Revenge Porn' and for Congress to Amend 47 U.S.C. § 230: How Our Current Laws Do Little to Protect Victims, 14 U. PitT. J. TECH. L. \& Pol'y 236 (2014) (offering a deeper look into the complexities of Internet Service Provider immunity under Section 230); but see Franklin, supra note 28 (arguing that this issue has never reached the Supreme Court and there are several ways around Section 230 that could be used by litigators in revenge porn cases).

37. See generally GoDaddy.com, LLC v. Hollie Toups, 429 S.W.3d 752 (Tex. Crim. App. 2014).

38. Id. at 752 .

39. Id. at 753 .

40. Id. at 760-62.

41. See generally Frequently Asked Questions, supra note 19.

42. Id.

43. Nina Bahadur, Victims of 'Revenge Porn' Open Up On Reddit About How It Impacted 
that she "oscillated between panic and persistent anxiety. [She] would wake up at $3 \mathrm{am}$ and check [her] email, [her] Facebook page, eBay, then Google [her] name, a ritual [she] performed three times before [she] could settle back down." ${ }^{44}$ Several women have reported being blackmailed, including one instance in which a revenge porn site operator in San Diego charged women up to $\$ 350$ to have their pictures removed because the operator knew the women were being harassed. ${ }^{45}$

\section{B. How Revenge Porn and Sexting Differ}

It is important to distinguish revenge porn from another recent phenomenon known as "sexting." Sexting occurs when individuals send sexually explicit, nude, or semi-nude photos to others via a cell phone. ${ }^{46}$ As one law review article suggests, sexting can be broken down into primary and secondary sexting. ${ }^{47}$ Primary sexting refers to the initial consensual transmission of the explicit images between two parties, while secondary sexting occurs when one party forwards the image via text message without the permission of the subject of the photo. ${ }^{48}$ There are seventeen states that have passed some form of sexting law, with three states that provide certain instances in which a violation is a felony and three states in which violators are not considered sex offenders. ${ }^{49}$ Current laws do not provide any special protection for a moment of indiscretion by teenagers who engage in secondary sexting when they forward a sext to another individual via a medium other than text message. ${ }^{50}$

There are four different roles involved in sexting, some of which may be held by the same person: (1) the person or people in the photo; (2) the photographer; (3) the distributor(s); and (4) the recipient(s). ${ }^{51}$ Sexting statutes that take into account secondary sexting may offer one remedy to the problem at hand if the

Their Lives, Huffington Post (Jan. 10, 2014, 8:50 AM), http://www.huffingtonpost.com/ 2014/01/09/revenge-porn-stories-real-impact_n_4568623.html [http://perma.cc/GVR6-Z7VV].

44. Id.

45. Laura McVicker, Man Accused of 'Revenge Porn' Made Victims 'Desperate: 'Attorney, NBC 7 SAN DiEGO (last updated Jan. 16, 2014), http://www.nbcsandiego.com/news/local/ManAccused-of-Revenge-Porn-Made-Victims-Desperate-Attorney-288877991.html [http://perma.cc/2MHE-3EP6].

46. Sexting Legislation in 2013, NAT'L Conf. ST. LeGIS. (Oct. 30, 2013), http://www. ncsl.org/research/telecommunications-and-information-technology/2013-sexting-legislation.aspx [http://perma.cc/T45R-XCFN] (information also on file with author).

47. Elizabeth M. Ryan, How the State Can Prevent a Moment of Indiscretion from Leading to a Lifetime of Unintended Consequences for Minors and Young Adults, 96 IowA L. REV. 357, 361 (2010).

48. Id.

49. Justin W. Patchin, Summary of State Sexting Laws, Cyberbullying Res. Ctr. (July 9, 2013), http://cyberbullying.us/summary-of-state-sexting-laws/ [http://perma.cc/BG6H-FRVD].

50. Ryan, supra note 47 , at 379.

51. Id. at 360-61. 
photograph is distributed via text, but the problem becomes more serious when the pictures or videos reach the Internet - a place where images can go viral within minutes of publication and may have more far reaching effects than sexting. ${ }^{52}$ It is at this precise point when images leave a text message or storage device and are leaked onto the Internet that revenge porn statutes should begin and sexting statutes should end. Revenge porn statutes should handle images that are distributed via Internet media while sexting statutes should remain focused on regulating a text-messaging device.

\section{Application to Minors}

The distinction between sexting and revenge porn as it applies to minors is important because differing statutes may ultimately determine how an individual is charged. Minors who consensually engage in primary sexting may not subjectively believe that a boyfriend, girlfriend, or other love interest will distribute these pictures to a third party after the relationship is broken off, but this does not matter. ${ }^{53}$ As one court has held in A.H. v. State, the objective nature of relationships among minors is fleeting. ${ }^{54}$ The court also held:

Neither [party has] a reasonable expectation that the other [will] not show [explicit photos] to a third party. Minors who are involved in a sexual relationship, unlike adults who may be involved in a mature committed relationship, have no reasonable expectation that their relationship will continue and that the photographs will not be shared with others intentionally or unintentionally. ${ }^{55}$

The court in that case went on to hold that both the boyfriend and girlfriend who shared graphic images with each other should be held liable for production and distribution of child pornography regardless of whether the images were intended to be private because the state has a legitimate interest in preventing the spread of child pornography. ${ }^{56}$

A recent survey by the Greater Manchester Police in the United Kingdom found that children as young as eleven have been victims of revenge porn. ${ }^{57}$ Many of the police reports examined in the study involved graphic images of minors that were posted by other minors, usually without the consent or knowledge of the minor depicted in the picture. ${ }^{58}$ Another study revealed that nearly $10 \%$ of

52. Id. at 375 .

53. See, e.g., A.H. v. State, 949 So. 2d 234, 241 (Fla. Dist. Ct. App. 2007).

54. Id. at 237.

55. Id.

56. Id. at 239 .

57. Laura Toogood, Of Course Children Are Revenge Porn Victims. They Value Popularity Over Privacy, TELEGRAPH (Oct. 1, 2014, 1:00 PM), http://www.telegraph.co.uk/women/womenslife/11133165/Children-are-revenge-porn-victims-because-they-value-popularity-over-privacy.html [http://perma.cc/FZY6-P5KE].

58. Id. 
minor-to-minor cases of sexting and non-consensual posting of pictures on the Internet led to blackmail, violence, and sexual abuse. ${ }^{59}$ In the United States, there were 3477 reported cases of youths that distributed sexual images via text message or social media between 2008 and $2009 .{ }^{60}$ The number of reported cases likely underestimates the actual frequency at which teenagers send these messages because many instances go unreported to police or parents. ${ }^{61}$

This same study identified the issue that is the focus of this Note: youths that engage in this activity are vulnerable to arrest for suspected distribution of child pornography. ${ }^{62}$ The study estimates that at least two-thirds of the examined cases involved images that would likely fall under federal and most state child pornography statutes. ${ }^{63}$ Although most of the youths that participated in this type of activity were not formally charged or arrested ${ }^{64}$ there remains a concern that the small percentage of cases involving sexual harassment, abuse, and blackmail may be a problem for police and legislators for many years to come. ${ }^{65}$

One example of the dangers of minors sending nude images of themselves to other minors is how quickly the image can spread through a school or over the Internet. In one case, a thirteen-year-old girl sent a topless photo of herself to her fourteen-year-old boyfriend ${ }^{66}$ After the two broke up, the boyfriend forwarded the image to several friends, many of whom in turn forwarded the photo to others. ${ }^{67}$ By the time police intervened several days later, more than 200 students had received the image. ${ }^{68}$ In another case, a girl refused to send more nude pictures of herself to a boy after he downloaded a picture she had accidentally uploaded to a social media site. ${ }^{69}$ The boy then sent the nude picture of the girl to about 100 people and was thereafter charged with a felony. ${ }^{70}$

What is particularly perplexing about this phenomenon is that the people closest to the minor often do not know that this activity is taking place or how to stop it from happening again. ${ }^{71}$ Parents generally do not understand how social media sites like Instagram or Facebook work and, accordingly, may not effectively monitor the privacy settings on a minor's account. ${ }^{72}$ This may lead to

59. Janis Wolak et al., How Often Are Teens Arrested for Sexting? Data From a National Sample of Police Cases, 129 PEDIATRICS 4, 8 (2012), available at http://pediatrics.aappublications. org/content/129/1/4.full.pdf+html [http://perma.cc/TRB3-XLVD].

60. Id. at 7 .

61. Id.

62. Id. at 8 .

63. Id. at 8-9.

64. Id. at 9 .

65. Id. at 8 .

66. Id. at 10 .

67. Id.

68. Id.

69. Id.

70. Id.

71. Toogood, supra note 57.

72. Id. 
confusion and frustration when parents do not understand how to block an unknown follower or subscriber. ${ }^{73}$

What causes teenagers to engage in this behavior in the first place? Arguably, many teenagers today value popularity over privacy; the shock value associated with pictures of intimate areas tends to drive up "likes" or "favorites" on social networking sites. ${ }^{74}$ Many teenagers want their friends to know of their sexual prowess and pictures of their exploits are used as evidence to prove what they have done. ${ }^{75}$ Once these pictures are on the Internet, however, a simple search by the subject's name often brings these pictures - many of which will be forever associated with that individual- to the front page. ${ }^{76}$

Additionally, teenagers are quick to upload pictures without the consent of the person in the photo and some teenagers even find it funny that other people do not want pictures of themselves on the Internet. ${ }^{77} \mathrm{Cell}$ phones are often readily available to minors who then can quickly capture an image and have it uploaded to their social media site almost instantaneously. ${ }^{78}$ The permanence of these images on the Internet gives rise to the need for statutes that will appropriately punish the wrongdoer and work to deter these acts from occurring in the first place.

\section{EXISTING LAW}

Currently, approximately half of states have no relevant laws that specifically address the issue of revenge porn..$^{79}$ Many of the states that have passed revenge porn legislation have done so without any special provisions for minor-to-minor transmission of graphic images. ${ }^{80}$ It is therefore important to examine the strengths and weaknesses of those statutes that already exist in order to formulate ways in which current statutes might be amended and future statutes should be drafted to address the issue of revenge porn among minors.

\section{A. New Jersey and California Statutes}

Two of the first states to pass revenge porn statutes successfully were California and New Jersey. ${ }^{81}$ These two statutes provide informative examples of what revenge porn statutes may, and perhaps should, look like. The statutes also serve as good examples of what punishments for those who violate the law can be. Analytically, these two laws are important because they create bookends to the spectrum of revenge porn laws that have already passed through state

73. Id.

74. Id.

75. A.H. v. State, 949 So. 2d 234, 237 (Fla. Dist. Ct. App. 2007).

76. Toogood, supra note 57.

77. Id.

78. Id

79. Hinduja \& Patchin, supra note 22, at 1.

80. Id.

81. Id. 
legislatures across the country.

The first state to enact any form of revenge porn law was New Jersey. ${ }^{82}$ Enacted in 2004, the relevant portion of the statute reads:

An actor commits a crime of the third degree if, knowing that he is not licensed or privileged to do so, he discloses any photograph, film, videotape, recording or any other reproduction of the image of another person whose intimate parts are exposed or who is engaged in an act of sexual penetration or sexual contact, unless that person has consented to such disclosure. For purposes of this subsection, "disclose" means sell, manufacture, give, provide, lend, trade, mail, deliver, transfer, publish, distribute, circulate, disseminate, present, exhibit, advertise or offer. ${ }^{83}$

Although not originally intended to encapsulate revenge porn, this statute offers broad language and "arguably applies to allow prosecution of an individual in a 'revenge porn' situation." 84

It is important to dissect this statute to understand the basic mechanics of how revenge porn statutes work and to allow for an easier comparison between statutes. First, the New Jersey statute makes it clear that the actor must know that he or she is releasing an image without the consent of the person who is exposed in the photograph. ${ }^{85}$ Second, the statute provides seventeen verbs to define the word "disclose." ${ }^{86}$ Finally, defendants are offered two affirmative defenses to this crime-either the actor gave the other person prior notice of the act that was about to occur or the actor acted with a lawful purpose ${ }^{87}$ If found guilty of this crime, the statute levies a "fine not to exceed $\$ 30,000 . " 88$

California formally criminalized revenge porn in $2013 .{ }^{89}$ As it was originally passed, the language of the statute read:

Any person who photographs or records by any means the image of the intimate body part or parts of another identifiable person, under circumstances where the parties agree or understand that the image shall remain private, and the person subsequently distributes the image taken, with the intent to cause serious emotional distress, and the depicted

82. Larson, supra note 34.

83. N.J. StAT. ANN. § 2C:14-9(c) (2004).

84. Suzanne Choney, 'Revenge Porn' Law in California Could Pave Way For Rest of Nation, NBC News (Sept. 3, 2013, 4:34 PM), http://www.nbcnews.com/tech/internet/revenge-porn-lawcalifornia-could-pave-way-rest-nation-f8C11022538 [http://perma.cc/EKW8-KRW9].

85. See N.J. StAT. AnN. § 2C:14-9(c) (stating that the actor must know "he is not licensed or privileged" to release the photograph of another person "unless that person has consented to such a disclosure").

86. See id. (defining the word disclose as "sell, manufacture, give, provide, lend, trade, mail, deliver, transfer, publish, distribute, circulate, disseminate, present, exhibit, advertise or offer").

87. Id. § $2 \mathrm{C}: 14-9(\mathrm{~d})(2)$.

88. Id. § $2 \mathrm{C}: 14-9(\mathrm{c})$.

89. Choney, supra note 84. 
person suffers serious emotional distress. ${ }^{90}$

Those who violated the statute could have been charged with a misdemeanor on their first offense and subsequently could have received up to a $\$ 1000$ fine, spent up to six months in jail, or both. ${ }^{91}$

When it was passed, California's law was heavily criticized because some felt it was drafted too narrowly. ${ }^{92}$ Additionally, the 2013 statute only applied if the person who took the photographs was the same person who distributed them. ${ }^{93}$ Notably, the 2013 version of the statute did not include selfies, which are pictures where the subject and the photographer are one in the same. ${ }^{94}$ This was problematic because if Person $A$ were to take a selfie and send it to Person $B$, and Person $B$ sent the picture out to Persons $C, D$, and $E$ without Person $A$ 's consent, Person $B$ 's actions would not give rise to criminal liability under this statute.

Recognizing the blatant omission of selfies from the code, California recently passed an amendment to the statute that addresses some of these issues. ${ }^{95}$ Currently, the statute reads:

Any person who intentionally distributes the image of the intimate body part or parts of another identifiable person, or an image of the person depicted engaged in an act of sexual intercourse, sodomy, oral copulation, sexual penetration, or an image of masturbation by the person depicted or in which the person depicted participates, under circumstances in which the persons agree or understand that the image shall remain private, the person distributing the image knows or should know that distribution of the image will cause serious emotional distress, and the person depicted suffers that distress. ${ }^{96}$

This law carries a punishment of up to a $\$ 1000$ fine, a jail sentence not to exceed six months, ${ }^{97}$ or both, and also includes increased penalties for repeat offenders. ${ }^{98}$

The amended version of California's law likely broadens the application of the original statute and focuses more on the non-consensual aspect of revenge porn. The new statute retains the element of intentional distribution of an intimate image with knowledge that the distribution will cause serious emotional distress to the victim. ${ }^{99}$ Furthermore, the revised law defines distribution as the act of

90. CAL. Pen. Code. $§ 647(j)(4)(A)$ (2013) (amended in 2014).

91. CAL. PEN. CODE $§ 19$ (1984).

92. Eric Goldman, California's New Law Shows It's Not Easy to Regulate Revenge Porn, Tech. \& Marketing L. Blog (Oct. 16, 2013), http://blog.ericgoldman.org/archives/2013/ 10/californias_new_1.htm [http://perma.cc/RXS2-NRZW].

93. $I d$.

94. $I d$.

95. See Cal. Pen. Code $\S 647(j)(4)(A)$ (2013) (amended in 2014).

96. Id.

97. Cal. Pen. Code $\S 19$ (1984).

98. CAL. Pen. Code $\S 647(l)(1)$ (2013) (amended in 2014).

99. See id. $\S 647(\mathrm{j})(4)(\mathrm{A})$. 
personally distributing, requesting that someone else distribute, or intentionally causing another to distribute an image ${ }^{100}$ Finally, three affirmative defenses are available when the distribution of the photograph is made: (1) when reporting an unlawful activity; (2) when necessary for a legal proceeding; (3) when needed for a lawful public proceeding. ${ }^{101}$ Under this revision, it would now appear that Person $B$ in the above scenario could be successfully prosecuted, so long as they possessed the requisite intent.

\section{B. Other States}

Since 2013, a total of thirteen states have enacted legislation to criminalize this practice. ${ }^{102}$ Most states impose similar penalties to those found in the California and New Jersey statutes, but each state may classify the conduct that constitutes revenge porn in a slightly different way. For example, Alaska, Colorado, and Maryland classify revenge porn as harassment and require an element of intent similar to California's statute. ${ }^{103}$

Alaska has a special provision for the act of sending an explicit image of a minor, but it fails to provide any special remedy for situations in which both parties are minors. ${ }^{104}$ The statute says that a person commits this offense when they distribute explicit photos "with [the] intent to annoy or humiliate another person" if the other person was under sixteen years of age at the time the picture was taken. ${ }^{105}$ Colorado's statute, on the other hand, only applies to people older than eighteen, but retains the "intent to harass" requirement of this category of statutes. ${ }^{106}$ Maryland's statute also appears only to apply to people over the age of eighteen, but punishes wrongdoers more severely with fines up to $\$ 5000$, jail time up to two years, or both. ${ }^{107}$

Alternatively, states like Arizona, Delaware, Georgia, and Hawaii each focus on the invasion of privacy suffered by the victim, which is more akin to the New Jersey statute. ${ }^{108}$ The Arizona statute retains an element of intent, but enhances the felony from class five to class four if the victim is identifiable. ${ }^{109}$ Delaware's statute reads similarly to New Jersey's statute, but also contains an express provision that a party who consented to an intimate photograph within a private or confidential relationship "retains a reasonable expectation of privacy with

100. Id. $\S 647(\mathrm{j})(4)(\mathrm{B})$.

101. Id. $\S 647(\mathrm{j})(4)(\mathrm{D})$.

102. State 'Revenge Porn' Legislation, supra note 26.

103. Alaska Stat. $\S 11.61 .120$ (2013); Colo. Rev. Stat. § 18-7-107 (2014); Md. Code ANN., CRIM. LAW § 3-809 (2014).

104. See Alaska Stat. $\S 11.61 .116$.

105. Id. $\S 11.61 .116(\mathrm{a})$.

106. Colo. Rev. Stat. $\S 18-7-107$.

107. Md. Code Ann., CRim. LaW § 3-809.

108. Ariz. Rev. Stat. Ann. § 13-1425 (2014); Del. Code Ann. tit., $11 \S 1335$ (2014); GA. Code AnN. § 16-11-90 (2014); Haw. Rev. Stat. § 711-1110.9 (2014).

109. ARIz. Rev. StAT. § 13-1425(c). 
regard to the reproduction ... of the visual depiction beyond that relationship." 110 Georgia's statute follows a similar pattern, but allows fines up to $\$ 100,000$ for a second offense. ${ }^{111}$ Finally, Hawaii's statute includes an element of intent to cause harm to the depicted person, but includes a list of damages that could be felt by the victim, including career, reputation, health, and safety. ${ }^{112}$

In 2014, at least twenty-eight states, Puerto Rico, and the District of Columbia passed or considered bills to combat revenge porn. ${ }^{113}$ Of particular note, Massachusetts State Representative Alan Silvia planned on introducing a bill in early 2014 that would specifically target minors who distribute revenge porn. ${ }^{114}$ The intent of the bill was to bring awareness to "public safety and mental health issue[s]." 115 The bill would have imposed a $\$ 250$ fine for a minor's first offense, $\$ 500$ for a second offense, and $\$ 1000$ and up to six months of jail time for each subsequent conviction. ${ }^{116}$ Proponents of the bill praised the monetary penalty this statute would impose because it would allow local authorities to use this punishment as a teaching tool about the dangers of sending non-consensual graphic images around the Internet. ${ }^{117}$ Opponents, however, believed these fines would just be passed on to parents, eliminating most educational value from the punishment. ${ }^{118}$

\section{Conflicting Remedies}

In criminalizing revenge pornography, there are legitimate concerns that First Amendment protections of freedom of speech could be infringed. ${ }^{119}$ The only state senator to vote against California's revenge porn bill in 2013 explained his opposition by saying, "While I appreciate the intent of this legislation, I feel it was too broadly drawn and could potentially be used inappropriately to censor free speech." 120 Other skeptics of revenge porn criminalization argue that most statutes are too stringent and that there should be a public interest exception, allowing the media to document and expose people, such as politicians, who are corrupt or are not fit for public office. ${ }^{121}$ Those who make this argument point to

110. Del. Code AnN. tit. 11, § 1335(b).

111. Ga. CODE ANN. § 16-11-90.

112. HAW. REV. STAT. § 711-1110.9.

113. State 'Revenge Porn' Legislation, supra note 26.

114. Brian Fraga, State Rep. Alan Silvia Seeks 'Revenge Porn' Penalties, MetroWest Daily News (Feb. 25, 2014, 6:12 PM), http://www.metrowestdailynews.com/article/20140225/News/ 140227775 [http://perma.cc/ED38-XFN7].

115. Id.

116. $I d$.

117. Id.

118. Id.

119. Choney, supra note 84.

120. Id.

121. Sarah Jeong, Revenge Porn Is Bad. Criminalizing It Is Worse, WIRED (Oct. 28, 2013, 9:30 AM), http://www.wired.com/2013/10/why-criminalizing-revenge-porn-is-a-bad-idea/ [http:// 
events like the political scandal involving New York politician Anthony Weiner, whose nude selfies were distributed to the media without his consent. ${ }^{122}$ There is also a worry that laws that try to draw a hard line between egregious speech and speech typically protected by the First Amendment are troublesome to enforce on constitutional grounds because the line is so subjective as to what material may be useful to alert the public to potentially shady politicians, as opposed to material that is simply private in nature. ${ }^{123}$

One argument that may be made for excluding revenge pornography from First Amendment protections is that the First Amendment should not protect this behavior because it is obscene in nature. ${ }^{124}$ Generally, First Amendment protections for pornography do not extend to acts or pictures that are obscene and have no artistic, educational, or medical value. ${ }^{125}$ The vindictive attribute of revenge porn extends beyond the scope of normal pornography. ${ }^{126}$ Classification of revenge porn as "obscene" would place it among the exceptions to the First Amendment. ${ }^{127}$ This recognition would provide "safeguards against unwanted publicity and notoriety stemming from the distribution of material that is damaging to a victim's psyche, well-being, reputation, and current and future job opportunities." ${ }^{, 128}$ Failure to recognize revenge porn as obscene would be akin to a permissive attitude toward these kinds of destructive exploitations and would provide no remedy to victims. ${ }^{129}$

In addition to First Amendment issues, there may be several unintended consequences of imposing criminal sanctions on violators of this law that must be taken into account. Broadly worded criminal statutes may increase intake at already crowded prisons or juvenile detention facilities by prosecuting individuals who neither originate the image nor intentionally distribute the photographs. ${ }^{130}$ Criminal sanctions may also be problematic because retribution may be misguided if images are posted, re-posted, shared, or distributed across the

perma.cc/TX99-8WFT].

122. See Choney, supra note 84 (indicating the need to balance individual rights with legitimate free speech issues); see also Jeong, supra note 121 (arguing that even tabloids should still be able to use their First Amendment protections to a certain extent when uncovering the truth about politicians who rely on their squeaky-clean image).

123. Cathy Reisenwitz, Revenge Porn is Awful, But the Law Against It Is Worse, Talking Points Memo (Oct. 16, 2013, 9:35 AM), http://talkingpointsmemo.com/cafe/revenge-porn-isawful-but-the-law-against-it-is-worse [http://perma.cc/395U-YDM8].

124. Benjamin A. Genn, What Comes Off, Comes Back to Burn: Revenge Pornography as the Hot New Flame and How It Applies to the First Amendment and Privacy Law, 23 AM. U. J. GENDER Soc. POL'y \& L. 163, 176 (2014).

125. Id. at $183-84$.

126. Id. at 184-85.

127. Id. at 192.

128. Id.

129. Id. at 193.

130. Larson, supra note 34. 
Internet by parties who did not originally publish the photo. ${ }^{131}$ Sending people to jail under these statutes may cause serious implications for first time offenders who are punished for acting irrationally after a breakup or disagreement with their significant other. ${ }^{132}$

A case may be made that laws of this nature will punish children and teenagers for their sexual exploits. ${ }^{133}$ Laws that punish teenagers "were enacted to protect young people rather than to criminalize them, but the legal outcomes have been frighteningly contradictory." ${ }^{334}$ Current trends suggest that as minors become more comfortable with the potential of technology, "they also become further victimized by the laws intended to protect them."135 A perfect example of this idea is when a minor is charged for possession and dissemination of child pornography, a statute otherwise meant to protect children from being exploited. ${ }^{136}$ Perhaps a more appropriate way to deal with this issue of punishment would be to assign probation officers or counselors that specialize in dealing with this kind of behavior to minors convicted under a revenge porn statute. ${ }^{137}$

Accordingly, a narrowly drafted criminal statute would be preferable in the case of revenge porn between minors. A narrow statute could exclude irresponsible posts of inappropriate pictures from minors who do not fully rationalize the potential harms that could come to them before posting pictures of themselves or their peers on social media. Conversely, criminal statutes are not likely to help the victim and only punish the wrongdoer. ${ }^{138}$ Other remedies, such as tort liability for public disclosure of private information or intentional infliction of emotional distress, may be more appropriate for gaining compensation for the victim. ${ }^{139}$

131. Id.

132. Id.

133. See generally Sonya Lahadon Rahders, Do as I Say, Not as I Do: Sexual Health Education and the Criminalization of Teen Sexuality in the United States, 26 HASTINGS WomEN's L.J. 147 (2015).

134. Id. at 149 .

135. Id. at 170.

136. See Randall, supra note 1 (referencing the student from Durfee High School in the introduction to this Note that distributed graphic images of girls from the high school without their consent).

137. Rahders, supra note 133, at 173.

138. See Jeong, supra note 121.

139. See generally Sexting-The Ineffectiveness of Current Law in Addressing the Phenomenon, Crim. Just. SeC. NewsL. (Am. BAR ASS'N), June 2009, available at http://www. americanbar.org/content/dam/aba/publishing/crimial_justice_section_newsletter/crimjust_juvjus t_newsletterjune09_june09_pdfs_sexting.authcheckdam.pdf [http://perma.cc/4ZFN-GRSS] [hereinafter Sexting]. 


\section{Potential Alternatives}

Criminal statutes are not the only way to address this phenomenon. This Part will address whether the law as it currently exists is sufficient to cure the problem at hand. As will be shown, existing remedies are inadequate for the purpose of correcting teenagers' behavior because each particular option could result in an unfair judgment for either the victim or the perpetrator of revenge porn.

\section{A. Child Pornography}

Although this Note argues against this outcome, one potential alternative to charging minors under a revenge porn statute is to charge them for distribution and/or possession of child pornography. For example, Indiana's statute on child exploitation and child pornography provides considerable protection for minors by classifying an offense for possession, dissemination, or production of child pornography as a Level 5 felony. ${ }^{140}$ The statute provides a defense if all of the following apply: (1) a cell phone, tablet, or social networking site were used to possess, produce, or disseminate the image; (2) the defendant is not more than 4 years older than the subject of the photograph; (3) the relationship between the defendant and the subject is a dating or serious relationship other than familial; (4) the crime was committed by someone less than twenty-two; and (5) the person receiving the image agreed to the defendant's conduct. ${ }^{141}$ Although this defense may offer some protection for minors who transmit images between themselves in a consensual manner, those minors who then transmit the images to a third party would no longer be eligible for the statutory defense and would fall under the purview of the law. ${ }^{142}$ Charging a minor under this statute would remain a relevant option under even the most egregious circumstances if a minor willingly engages in the production and distribution of child pornography. However, those unlikely cases are not the focus of this Note.

The federal child exploitation statute is broadly written to encompass more types of behavior. ${ }^{143}$ The statute defines child pornography as "any visual depiction, including any photograph, film, video, picture, or computer or computer-generated image or picture, whether made or produced by electronic, mechanical, or other means, of sexually explicit conduct."144 This statute imposes a penalty of no less than fifteen years in prison. ${ }^{145}$ This penalty would not be a favorable result for the majority of teenagers who might qualify for prosecution under this statute. Accordingly, state intervention may be more appropriate so as to give local authorities greater control to regulate this activity properly.

In most jurisdictions, a child convicted under child pornography laws will

140. IND. CODE $§ 35-42-4-4$ (b) (2014).

141. Id. § 35-42-4-4(f).

142. Id. § 35-42-4-4(g).

143. See 18 U.S.C. $\S 2256$ (2006).

144. Id. § 2256(8).

145. Id. $\S 2251(\mathrm{e})$. 
fight an uphill battle for the rest of his or her life. ${ }^{146}$ Difficulties may include registering as a sex offender every time the child moves locations, disclosing his or her status as a sex offender on all job applications, and being restricted on where he or she may live in relation to a school or church in a community. ${ }^{147}$ For these reasons, it would be wise to give a prosecutor better tools than child pornography statutes to use in charging a minor for distributing this kind of material.

\section{B. Civil Statutes}

Civil suits are another alternative to criminal statutes that may be used to punish a wrongdoer and potentially provide damages to victims of revenge porn. For example, a successful tort claim for intentional infliction of emotional or mental distress requires only a preponderance of the evidence standard for burden of proof. ${ }^{148}$ If successful, civil suits could also provide monetary compensation for the victim. However, the potential shortfall of civil suits is that any damages awarded will likely be borne by the parents; therefore, it would not provide an adequate teaching tool to prevent future behavior by the teenager.

Another suggestion is that victims of revenge porn could be protected under copyright statutes. ${ }^{149}$ Several law review articles have explored this topic and argue that copyright laws offer valid protections for victims because the victims may claim that the photographs are their original property. ${ }^{150}$ Arguably, however, copyright may not provide an adequate remedy to a minor because child pornography is already expressly prohibited by state and federal statute. ${ }^{151}$

\section{School Intervention}

One novel approach to forgoing criminal punishment for minors who engage in revenge porn would be to have schools intervene to correct and monitor the behavior. Schools arguably have an interest in protecting students when they use poor judgment in posting suggestive photos on social networking sites. ${ }^{152}$

146. Sexting, supra note 139.

147. Id.

148. See generally Daniel Zharkovsky, "If Man Will Strike, Strike Through the Mask": Striking Through Section 230 Defenses Using the Tort of Intentional Infliction of Emotional Distress, 44 Colum. J.L. \& Soc. Probs. 193 (2010).

149. See, e.g., Derek E. Bambauer, Exposed, 98 MinN. L. REv. 2025 (2014); Rebecca Tushnet, Performance Anxiety: Copyright Embodied and Disembodied, 60 J. COPYRIGHT SOC'Y 209 (2013); but see Rebecca Tushnet, How Many Wrongs Make a Copyright?, 98 Minn L. REv. 2346 (2014).

150. See, e.g., Bambauer, supra note 149; Tushnet, supra note 149; but see Tushnet, supra note 149.

151. See 18 U.S.C. $§ 2256$ (2012) (prohibiting possession and dissemination of child pornography).

152. See T.V. v. Smith-Green Community School Corporation, No. 1: 09-CV-290-PPS, 2011 WL 3501698 (N.D. Ind. August 10, 2011), EDUC.L.Ass'N (Oct. 8, 2014), https://educationlaw.org/ featured-caselaw/5643-tv-v-smith-green-community-school-corporation-no-1-09-cv-290-pps-2011- 
However, in T.V.v. Smith-Green Community School Corp., a federal district court held that a school could not suspend two students due to pictures they posted on their own time and off of school property. ${ }^{153}$

In that case, two girls from Churubusco High School in Indiana received a six-game suspension from the volleyball team by the school's administration after several suggestive photos were posted by the teens on their personal Facebook pages. ${ }^{154}$ The students argued that their First Amendment rights were being infringed upon because the images were expressive in nature and intended to be funny to the targeted audience. ${ }^{155}$ The court ultimately awarded summary judgment to the students on the issue of First Amendment rights, holding "[i]t would be an unseemly and dangerous precedent to allow the state, in the guise of school authorities, to reach into a child's home and control his/her actions there to the same extent that it can control that child when he/she participates in school sponsored activities." 156

The Supreme Court previously held that schools have a legitimate interest in protecting students from offensive speech. ${ }^{157}$ This standard may not apply to revenge porn statutes unless the students are using school-owned equipment to transmit the imagery. Furthermore, the pictures would likely have to be taken on school property or involve school logos to fall under this protection given the ruling in Smith-Green Community School Corp.

\section{PROPOSED REMEDY}

The purpose of this Note is to examine how best to handle the phenomenon of revenge porn among minors. Action is needed to punish a minor's conduct appropriately without giving them a permanent label of "sexual predator." With this goal in mind, the remedies in Part III miss the mark because they either overpunish the wrongdoer or provide little to no deterrence or rehabilitative value to the perpetrator. Part IV will recommend a strategy for drafting a criminal statute to target this conduct among minors with appropriate punishments for the severity of the conduct.

\section{A. Guidelines}

When drafting a revenge porn statute that contains special provisions for minors, it is important to consider the best aspects of existing and proposed

wl-3501698-nd-ind-august-10-2011 [http://perma.cc/M2XP-DL53].

153. T.V. v. Smith-Green Cmty. Sch. Corp., 807 F. Supp. 2d 767, 784-85 (N.D. Ind. 2011).

154. Id. at 771 .

155. See id. at 775-76 (noting that these images were shared on several sites, but on Facebook, the images were only shared with friends and not open to public consumption).

156. Id. at 784-85 (quoting Layshock v. Hermitage Sch. Dist., 650 F.3d 205, 216 (3d Cir. 2011)).

157. Bethel Sch. Dist. No. 403 v. Fraser, 478 U.S. 675, 687-88 (1986); see also Jamie L. Williams, Teens, Sexts, \& Cyberspace: The Constitutional Implications of Current Sexting \& Cyberbullying Laws, 20 WM. \& MARY BILL RTS. J. 1017, 1021 (2012). 
legislation. Mary Anne Franks, a professor at the University of Miami School of Law, is a noteworthy scholar in the area of revenge porn and has offered her thoughts on what an effective revenge porn statute should look like. ${ }^{158}$ Franks provides a compelling analysis of how existing statutes might be strengthened and her work offers a valuable foundation on which to formulate a workable statute for minors.

According to Franks, a revenge porn statute should set out the elements of the offense in a clear, straightforward manner. ${ }^{159}$ For example, preferred wording would be: "the knowing disclosure of sexually explicit photographs and videos of an identifiable person when the discloser knows or should have known that the depicted person has not consented to such disclosure." 160 This would be useful for statutes aimed at minors because it helps cover individuals who arguably did not know the person in the photographs did not consent to publishing the photograph. ${ }^{161}$

Franks also suggests the statute should allow for situations in which disclosure is made voluntarily and consensually, with very narrow exceptions for "disclosures made in the public interest." 162 There is no benefit to include this suggestion in a statute targeting the conduct of minors because the act of voluntary or consensual disclosure in these cases could be easily construed and thus prosecuted as child pornography.

Another important component of a revenge porn statute is that it should be clear that the mens rea for this offense is "intent to cause emotional distress." 163 It is difficult, however, to determine whether this element of intent would be appropriate for minors. The language "intent to cause emotional distress" is ambiguous as it applies to minors who may not otherwise know what they are doing is wrong or have no real intent to cause emotional distress. In order for the statute to target, more appropriately, minors who do not otherwise know what they are doing is wrong, one solution would be to adopt the culpable state of mind format of the Model Penal Code and adjust the penalties and punishments accordingly to give a prosecutor greater flexibility in charging the correct level of offense. ${ }^{164}$ This would mean that, at minimum, a minor could be brought under the statute's purview by purposely, knowingly, recklessly, or negligently distributing graphic pictures of others without their consent. ${ }^{165}$

Franks also recommends the statute should be carefully drafted to fit the

158. Mary Anne Franks, Drafting an Effective 'Revenge Porn' Law: A Guide for Legislators, SOC. SCI. RES. NETWORK (July 25, 2014), http://papers.ssrn.com/sol3/papers.cfm?abstract_id= 2468823 [http://perma.cc/2UBT-R4P5].

159. Id.

160. Id.

161. See id.

162. Id.

163. Id.

164. See Model Penal Code $§ 2.02$ (Proposed Official Draft 1964).

165. See id. 
scope of the graphic content it intends to encompass. ${ }^{166}$ Statutory language that defines something like the term "intimate parts" should not be broadly drafted to encompass things like drawings or "too much skin." 167 Conversely, this definition should not be written so narrowly as to exclude certain sexual acts. ${ }^{168}$

Finally, to broaden the scope of parties who may be prosecuted under a revenge porn statute, Franks argues the definition of distribution should include distribution of an image by persons other than a former significant other. ${ }^{169}$ This broader group of people would be especially important for minors who may not necessarily have a significant other, but possess pictures from potential love interests or classmates.

\section{B. Examples from Existing State Statutes}

As stated above, Franks's recommendations establish a good foundation for an effective revenge porn statute. Because her recommendations are mostly theoretical, existing statutes may also provide a good starting point for a draft statute because the provisions have already gone through legislative review and may have received the benefit of amendments throughout the years. As previously discussed in this Note, California and New Jersey present two different ways in which a revenge porn statute might be drafted. ${ }^{170}$

These two statutes have several similarities. First, both statutes allow perpetrators to be prosecuted for distributing intimate pictures of a person regardless of who first took the picture. ${ }^{171}$ Including this provision in a statute would be important, especially in the context of minor-to-minor transmission, because new technologies are giving teenagers more access to devices that take and distribute pictures. ${ }^{172}$ Additionally, both statutes allow an exception for people who distribute the photograph for a public purpose. ${ }^{173}$ This exception is important in allowing public access to important and relevant information, ${ }^{174}$ but could become difficult when it is applied to cases where images of children are involved because it is hard to imagine an instance in which distribution of explicit pictures of children would be appropriate or in the public interest.

There are several significant differences between these statutes as well. Primarily, the California statute requires that the distributor either "knows or

166. Franks, supra note 158.

167. Id.

168. Id.

169. Id.

170. Compare Cal. Pen. Code. § 647(j)(4)(A) (2015), with N.J. Stat. AnN. § 2C:14-9 (2004).

171. Compare Cal. Pen. Code. § 647(j)(4)(A), with N.J. Stat. AnN. § 2C:14-9.

172. Wolak et al., supra note 59 , at 8.

173. Compare Cal. Pen. Code § 647(j)(4)(D)(i), with N.J. Stat. Ann. § 2C:14-9(d)(2).

174. See, e.g., Jeong, supra note 121 (arguing that even tabloids should still be able to use their First Amendment protections to a certain extent when uncovering the truth about politicians who rely on their squeaky-clean image). 
should know that distribution of the image will cause serious emotional distress." 175 Conversely, the New Jersey provision does not contain any language relating to the intent or knowledge of the distributor - that they would cause emotional distress. ${ }^{176}$ As previously discussed, it would be important for a statute targeted at minors to include multiple levels of intent in order to charge the offense appropriately, based on the conduct of the distributor.

Further, the New Jersey statute defines disclosure in very specific terms, while the California statute only uses the word "distributes" to describe how the photos are released.$^{177}$ Finally, the two statutes offer differing penalties, with New Jersey imposing a fine of less than $\$ 30,000$, while California only imposes a $\$ 1000$ fine that could be paired with up to six months in jail for the first offense. ${ }^{178}$ Keeping in mind this statute will target conduct among minors, it may be wise to set a low dollar amount for any penalty imposed so as not to unduly burden a parent or child.

There are several provisions from other states that could also be helpful in drafting a comprehensive statute. Alaska's statute only protects a minor if he or she is under the age of sixteen when the picture was taken. ${ }^{179}$ To encapsulate more people, it may be wise to extend that age to eighteen. Arizona's statute provides an enhancement if the person in the photograph is identifiable. ${ }^{180}$ It is hard to say whether it would make a difference that the subject of a photograph can be recognized if the intent of this legislation is to prevent teenagers from taking part in the general act of revenge pornography. Delaware's statute requires there be a reasonable expectation between the parties that the image would remain private. ${ }^{181}$ A "reasonable expectation" may be too ambiguous, especially due to the fleeting nature of teenage relationships. ${ }^{182}$ Finally, Georgia provides that a second conviction under its statute would result in a $\$ 100,000$ fine. ${ }^{183}$ This provision would be unrealistic as applied to minors because these costs would likely be passed on to family members and there would be little to no educational value in the conviction. ${ }^{184}$

\section{Draft Statute}

Keeping the above recommendations in mind, a companion statute to existing or proposed revenge porn statutes should read as follows ${ }^{185}$ :

175. CAl. Pen. Code $\S 647(\mathrm{j})(4)(\mathrm{A})$.

176. See N.J. Stat. AnN. § 2C:14-9(c).

177. Compare § Cal. Pen. Code 647(j)(4)(A), with N.J. Stat. Ann. § 2C:14-9(c).

178. Id.

179. Alaska Stat. § 11.61 .116 (2013).

180. ARIZ. Rev. STAT. § 13-1425 (2014).

181. Del. Code AnN. tit. 11, § 1335 (2014).

182. See A.H. v. State, 949 So. 2d 234, 237 (Fla. Dist. Ct. App. 2007).

183. Ga. Code AnN. § 16-11-3 (2014).

184. See Fraga, supra note 115.

185. See Franks, supra note 158. The proposed statute is loosely based on the model state law 
1. A minor may not intentionally or knowingly disclose a sexually explicit photograph or video of another identifiable minor whose intimate parts are exposed or who is engaged in a sexual act, when the discloser knows or should have known that the depicted person did not consent to the publishing of the photograph or video.

a. Definitions. ${ }^{186}$ For the purposes of this section,

i. "Minor" includes any person under the age of eighteen at the time the explicit photograph or video is taken;

ii. "Disclose" includes transferring, transmitting, publishing, distributing, or reproducing a photograph or video via physical or digital copy over the Internet or other data device;

iii. "Intimate parts" means the naked genitals, pubic area, anus, or female nipple of the person;

iv. "Sexual act" includes masturbation, genital stimulation, or vaginal, anal, or oral sex.

b. Exceptions. This section does not apply to disclosures made in the public interest, including but not limited to the reporting of unlawful conduct, or the lawful and common practices of law enforcement, criminal reporting, legal proceedings, or medical treatment.

2. Penalties.

a. It shall be a Class D Misdemeanor if the photographs or videos are purposefully distributed with the intent to cause emotional or mental distress and without the consent of the person or persons depicted in the photographs or videos.

b. It shall be a Class A Infraction if the photographs or videos are knowingly distributed without the consent of the person or persons depicted in the photographs or videos.

c. It shall be a Class B Infraction if the photographs or videos are recklessly or negligently distributed without the consent of the person or persons depicted in the photographs or videos.

This statute does include an element of intent, but does not require that the perpetrator know that the distribution of the photographs could cause emotional distress or harm. This addresses the need for a narrowly tailored statute that targets teenagers who act on hormone-driven impulses without considering the emotional damage that could occur. The mens rea further breaks down into purposeful, knowing, or reckless disclosure. This allows prosecutors to assess the situation more accurately and could lead to a more appropriate punishment structure depending on the severity of the perpetrator's actions.

The statute also includes a straightforward definition section that allows some room for interpretation as to what constitutes a sexual act. As previously discussed, the definition section attempts to avoid two extremes of statutory construction. The definitions are not overly broad so as to include things like

proffered by Mary Anne Franks.

186. See id. These definitions and exceptions sections are also based on Mary Anne Franks' recommendations for a model state statute. 
hand-drawn pictures. Alternatively, the definitions are not too narrow so as to omit sexual acts or types of photographs like selfies from scrutiny under the statute.

The proposed statute includes several exceptions as well. The most important exceptions are those that deal with medical or criminal reporting. The wording of this proposal helps avoid potential conflict with lawful investigations and medical recommendations.

Finally, the different levels of punishment provide that commission of this crime will result in lower level offenses that could serve as a cautionary warning to a convicted minor. Perhaps a better solution for this punishment structure would be to require a probationary period with community service or meetings with a probation officer who is trained to deal with these kinds of situations. A second offense could then result in a low level fine or a small amount of jail time depending on the severity of the teen's behavior. These penalties would vary in accordance to an individual state's penalty structure and codification.

\section{CONCLUSION}

To be clear, charging a minor with possession and dissemination of child pornography for a moment of indiscretion carries serious and real consequences. ${ }^{187}$ Not only could a minor convicted under a state or federal child pornography statute be required to register as a sex offender, but they could also be severely limited in the kinds of jobs for which they qualify. ${ }^{188}$ For the studentperpetrator at Durfee High School in the opening paragraphs of this Note, these hypothesized results could become a harsh reality. ${ }^{189}$

Revenge porn statutes provide a unique opportunity to target this specific conduct among minors because they offer language that can be specifically tailored to this practice. The criminal code is an appropriate home for revenge porn statutes for minors because it allows prosecutors to charge the appropriate level of harm for children who take part in this act. ${ }^{190}$ The proposed statute in this Note targets this conduct in a multi-faceted manner and gives prosecutors an alternative to child pornography statutes.

Teenagers will be teenagers. Stopping the transmission of graphic images would be nearly impossible unless parents or guardians were to take away smartphones or social media privileges from teenagers. Educating parents and teenagers on the dangers of social media and smartphones is certainly important, but until society can achieve uniform education on this issue, the proposed remedy found in this Note will help protect minors from one of their biggest threats: themselves.

187. Sexting, supra note 139.

188. Id.

189. See Randall, supra note 1.

190. Sexting, supra note 139. 